\title{
Effects of provenance on the survival, growth and stem form of European silver fir (Abies alba Mill.) in Britain
}

\author{
Gary Kerr • Victoria Stokes • Andrew Peace • \\ Richard Jinks
}

Received: 14 August 2014/Revised: 23 October 2014/ Accepted: 27 October 2014/Published online: 22 January 2015

(C) The Author(s) 2015. This article is published with open access at Springerlink.com

\begin{abstract}
European silver fir (Abies alba Mill.) was the first true fir to be introduced to Britain in 1603. Despite early enthusiasm for the species, it has not been widely planted and work on the effects of silver fir woolly aphid (Adelges nordmannianae Eckstein) in the mid-twentieth century concluded that large scale use of the species could not be justified. This was interpreted as a research challenge and resulted in the establishment of a series of provenance experiments being established between 1966 and 1970. Results from these experiments after 46 years clearly show that European silver fir is a productive species and could be deployed in British forests as a component to diversify species composition and in the wider use of continuous cover forestry. In general, the trials show that good provenances survive and grow on a wide range of sites and it is not necessary to select different provenances depending on site location or climate. Provenances from Calabria in Italy performed very well and should be the first choice of origin for future planting in Britain. However, provenances from a wide range of the species natural distribution performed well demonstrating that European silver fir is a very adaptable species.
\end{abstract}

Communicated by C. Ammer.

Electronic supplementary material The online version of this article (doi:10.1007/s10342-014-0856-9) contains supplementary material, which is available to authorized users.

G. Kerr $(\bowtie) \cdot$ V. Stokes $\cdot$ R. Jinks

Forest Research, Alice Holt Lodge, Wrecclesham, Farnham,

Surrey GU10 4LH, UK

e-mail: gary.kerr@forestry.gsi.gov.uk

A. Peace

Forest Research, Northern Research Station, Roslin,

Midlothian EH25 9SY, UK
Keywords European silver fir · Provenance $\cdot$ Silviculture

\section{Introduction}

European silver fir (Abies alba Mill.) is a non-native species in Britain, but it was one of the earliest conifers introduced; records show it was first planted in 1603 (MacDonald et al. 1957). Subsequently, it has been planted as a specimen tree but has never become a widely used forest tree, although a provisional yield table for it was published by Maw (1912). Lines (1960) attributes the lack of popularity of the species to 'the impatience of nineteenth century foresters who preferred the much faster-starting conifers such as Douglas-fir and the well tried Norway spruce'. There was an increase in interest in the species in the early twentieth century prompted by the policy of forest expansion and the consequent research focus on choice of species and rate of growth of conifers (Pringle, 1994). However, the silver fir woolly aphid (Adelges nordmannianae Eckstein) became a serious problem in many of these new plantings causing needle distortion and shoot dieback and, following a period of study, Varty (1956) concluded that the risk of infestation was too high to justify the large scale use of European silver fir. This phrase became accepted wisdom with the result that in 2010 only 402 hectares of the European silver fir were recorded in Britain, just $0.02 \%$ of the forest area (Mason 2013).

The chequered history of European silver fir as a forest tree in Britain may not reflect its potential. Macdonald et al. (1957) indicate that the species has much to offer: it can produce high volumes of quality timber; it is windfirm and tolerant of exposure, which could be useful in an oceanic climate; the species is also resistant to Annosum root rot (Heterobasidion annosum (Fr.) Bref) in central 
Europe (Capretti et al. 1990), and its bark has relatively low vulnerability to extraction damage (Metzler et al. 2012; Kohnle and Kändler 2007). In addition, it is shade tolerant and well suited to attempts to diversify forest structure through the use of continuous cover forestry (Mason 2013; Puettmann et al. 2009). These qualities need to be balanced against the possible drawbacks of the species (Macdonald et al. 1957): slow early growth, sensitivity to frost, palatability to browsing damage and, as described above, the impact of silver fir woolly aphid. Diversification is a major theme of forest policy in Britain and it is now timely, once again, to review the potential contribution of a range of different species. The main drivers of this are the increasing impacts of pests and pathogens on a forest estate dominated by just five species (Forestry Commission 2011) and the need to diversify forests through the use of a wider range of silvicultural systems (Kerr 1999); central to this latter point is the need to identify a range of shade tolerant conifers (Paterson 1990).

The work of Lines (1960) on European silver fir is notable and was dominated by concerns about the woolly aphid. His conclusion is comprehensive and worth repeating here: 'this fact [the problem with Adelges] makes wide scale planting inadvisable, but it is also a challenge to research. We need to discover whether the wrong provenances have been used in the past, whether we can get satisfactory results with seed from homecollected provenances, which have survived Adelgid attacks or whether we can reduce the attack by better silvicultural methods or chemical control. Until these problems have been investigated, it is too early to write off European silver fir as an unsuitable species in British forestry'. This line of thinking was also pursued by Kerr (1999) who thought that much of the early work had trialled the species under conditions to which it was not well suited, i.e. in single-species plantations on open ground (Jahn 1976), and also questioned the scientific basis for the advice not to plant the species because of the risks of damage caused by the woolly aphid.

Fortunately, during the 1960s, a series of provenance experiments was established to help address some of the questions raised in the work of Lines $(1960,1979)$. The natural range of European silver fir covers a wide range of latitude and altitude, and provenances were selected within this range that were likely to perform well based on early results from trials in Denmark (Lofting 1954) and Italy (Pavari 1951) (both quoted in Lines 1960). These trials provide the main source of data examined in this paper, the objectives of which are:

1. To examine the effect of provenance on the survival, growth and stem form of European silver fir on a range of different sites in Britain.
2. To consider results in terms of important pests and pathogens of European silver fir in Britain.

3. To review the role of European silver fir in the silviculture of forestry in Britain.

\section{Materials and methods}

During the mid-1960s, a number of experiments were established by the Forestry Commission to examine the effect of provenance on the growth of European silver fir in Britain. The objective stated in the experiment plan was 'to compare the survival, growth, resistance to disease and pests and any other factor of different provenances of $A$. alba from nine countries'. Sites were chosen in Scotland, England and Wales, to represent a wide range of site conditions. Initially, there were five main experiments and three smaller trials (Fig. 1; Table 1); the latter contained different provenances to the main experiments or had a different experimental design. One of the main experiments at Lael, which had 44 provenances including one from the Glendye Estate in Scotland, was closed after 6 years due to

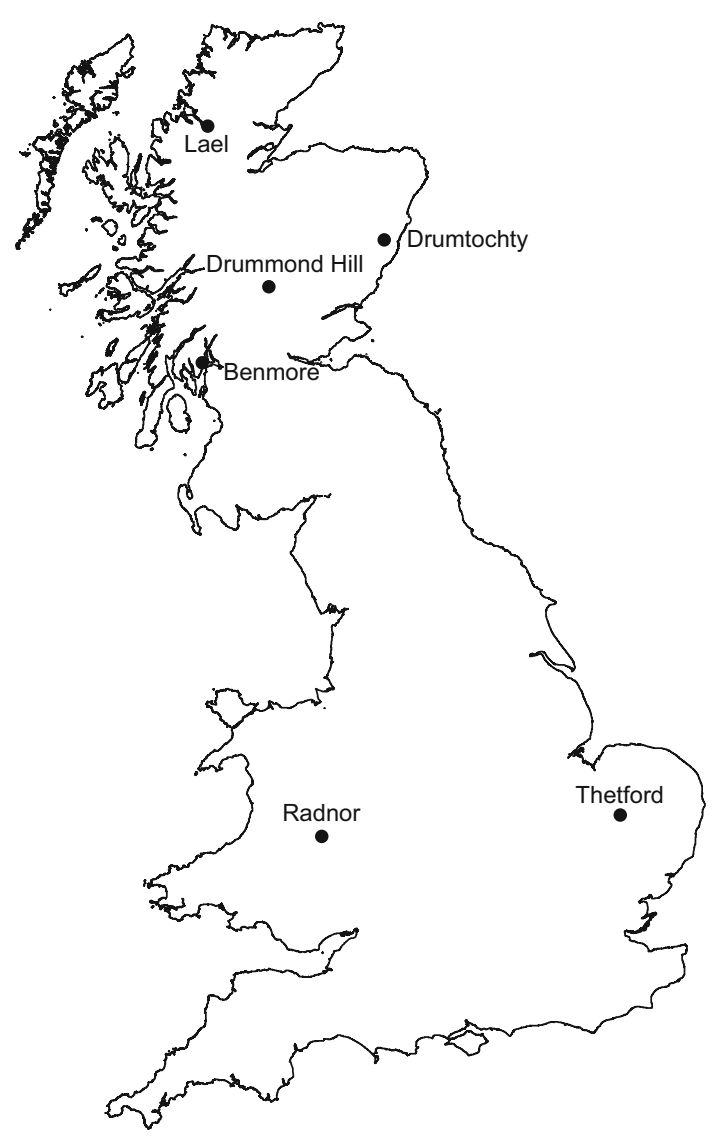

Fig. 1 Map of Britain showing location of provenance trial sites 
Table 1 Characteristics of provenance trial sites

\begin{tabular}{|c|c|c|c|c|}
\hline & \multicolumn{4}{|l|}{ Trial site } \\
\hline & Benmore & Drummond Hill & Radnor & Thetford \\
\hline Grid ref & NS 179817 & NN 752462 & SO 187678 & TL 824851 \\
\hline Lat, long & $55^{\circ} 59^{\prime} \mathrm{N}, 4^{\circ} 55^{\prime} \mathrm{W}$ & $56^{\circ} 35^{\prime} \mathrm{N}, 4^{\circ} 02^{\prime} \mathrm{W}$ & $52^{\circ} 18^{\prime} \mathrm{N}, 3^{\circ} 11^{\prime} \mathrm{W}$ & $52^{\circ} 26^{\prime} \mathrm{N}, 0^{\circ} 41^{\prime} \mathrm{E}$ \\
\hline Elevation (m above sea level) & $60 \mathrm{~m}$ & $290 \mathrm{~m}$ & $410 \mathrm{~m}$ & $40 \mathrm{~m}$ \\
\hline Aspect & SSW & NW & NNW & SE \\
\hline Rainfall (mean annual, mm) & 2,290 & 1,190 & 1,100 & 620 \\
\hline Exposure (DAMS score ${ }^{\mathrm{a}}$ ) & 14.4 & 11.1 & 14.9 & 12.3 \\
\hline Slope & Moderate to very steep & Moderate to steep & Moderate to steep & Flat \\
\hline Soil nutrient regime ${ }^{a}$ & Medium & Medium & Medium & Poor \\
\hline Soil moisture regime ${ }^{\mathrm{a}}$ & Fresh & Fresh & Fresh & Slightly dry \\
\hline Geology & Mica schists & Mica schists & Silurian shale & Glaciofluvial drift and till \\
\hline Soil $^{\mathrm{b}}$ & $\begin{array}{l}\text { Upland brown earth, } \\
\text { very stoney }(>35 \%) \\
\text { in places ( } 1 \mathrm{u} / 1 \mathrm{us})\end{array}$ & $\begin{array}{l}\text { Upland brown earth } \\
\text { (shallow)/intergrade } \\
\text { ironpan very stoney } \\
(>35 \%) \text { in places } \\
(1 \mathrm{ua} / 4 \mathrm{bs})\end{array}$ & Upland brown earth $(1 \mathrm{u})$ & Podzolic brown earth $(1 \mathrm{z})$ \\
\hline ESC $_{\text {species suitability }}{ }^{\mathrm{c}}$ & Suitable (12; AT5) & Suitable (10; AT5) & Suitable (10; AT5) & Marginal (8; MD) \\
\hline $\begin{array}{l}\text { ESC species suitability for } \\
2,050 \text { (high) IPCC } \text { scenario }^{c}\end{array}$ & Unsuitable $(0 ; \mathrm{MD})$ & Very Suitable $(16 ; \mathrm{CT})$ & Unsuitable $(0 ; \mathrm{MD})$ & Unsuitable $(0 ; \mathrm{MD})$ \\
\hline
\end{tabular}

${ }^{a}$ See Ecological Site Classification of Pyatt et al. (2001) and Ray (2000)

b According to Kennedy (2002)

c As defined by Ecological Site Classification of Pyatt et al. (2001) and Ray (2000). Figures in brackets are GYC for European silver fir and main limiting factor in ESC. General yield class (GYC) is a classification of the rate of growth in terms of potential maximum mean annual volume increment per hectare

browsing damage. Therefore, this paper reports on the results from the remaining four experiments ${ }^{1}$.

The experiments were established in the mid-1960s (Table 2) by underplanting recently thinned European larch (Larix europaea (Mill.)) overstories (Scots pine (Pinus sylvestris (L.)) overstorey at the Thetford site) planted between 1923 and 1932. Each experiment was a randomised block with provenance as the treatment and three replicates. Due to plant supply problems, not every provenance was present at each site and some were only present in two of the three blocks (Table 3). The provenances were selected to cover the natural range of the species (Fig. 2), with emphasis on areas which had given good results in other European experiments (Lines 1960). For comparative purposes, one provenance of grand fir (Abies grandis L.) was included at each site and at Thetford and Drummond Hill one provenance of Caucasian fir (Abies nordmanniana (Stev.) Spach) was also included.

\footnotetext{
${ }^{1}$ Results from the three smaller trials and the main experiment that was closed after 6 years at Lael are described in the Supplementary Material. The three smaller trials comprised of five additional provenances that were added to the Drummond Hill site in 1966; another experiment trialling 14 Czechoslovakian provenances planted adjacent to the Drummond Hill experiment in 1970; and a number of larger 'demonstration' plots at Drumtochty.
}

The experiments at Lael, Drummond Hill and Thetford were selected as having overstories with high infection of Annosum root rot, which was an important disease that could not be controlled when the experiments were established.

All the plants for these experiments were raised at the Forestry Commission nursery at Fleet in southwest Scotland. They were planted out in the experiments as 5-7year-old stock having been transplanted at least once. In the year before planting, they were affected by a very late frost in May 1965 and the form of the trees at the time was described as 'badly damaged'. The size of the A. alba trees was generally small, and records indicate heights of $10-30 \mathrm{~cm}$. The grand fir and Caucasian fir were supplied from Newton nursery (near Inverness, Scotland) and were 4-year-old transplants with a height of 30-50 cm.

Plots contained 36 trees $(6 \times 6)$ that were notch planted at five foot spacing $(1.52 \times 1.52 \mathrm{~m})$, except at Thetford where spacing was $4 \frac{1}{2} \times 4^{1 / 2}$ foot $(1.37 \times 1.37 \mathrm{~m})$ which was local practice at the time. All trees were planted at least $1 \mathrm{~m}$ from an overstorey tree. There was an unplanted row between plots at Benmore, and two at Radnor; plots at Thetford and Drummond Hill were planted without empty rows. There was an unplanted row between blocks at all sites and a two-row surround of European silver fir 
Table 2 Details of establishment and stand conditions for each site

\begin{tabular}{|c|c|c|c|c|}
\hline & \multicolumn{4}{|l|}{ Trial site } \\
\hline & Benmore & Drummond Hill & Radnor & Thetford \\
\hline $\begin{array}{l}\text { Previous } \\
\text { land use }\end{array}$ & Sheep grazing & $\begin{array}{l}\text { Rough open grazing with } \\
\text { some birch }\end{array}$ & Sheep grazing & Not recorded \\
\hline Overstorey & $\begin{array}{l}\text { EL planted in } \\
1927\end{array}$ & EL planted 1923 & EL planted in 1932 & SP planted 1927 \\
\hline $\begin{array}{l}\text { Overstorey } \\
\text { thinned }\end{array}$ & $\begin{array}{l}\text { Heavily in Dec } \\
1965\end{array}$ & Summer 1964 & 1965 & 1965 \\
\hline Planting date & May 1966 & Apr 1965 & Mar 1966 & Apr 1966 \\
\hline $\begin{array}{l}\text { Vegetation } \\
\text { before } \\
\text { planting }^{\mathrm{a}}\end{array}$ & $\begin{array}{l}\text { Soft grasses, } \\
\text { ferns, some } \\
\text { bracken. }\end{array}$ & $\begin{array}{l}\text { Deschampsia flexuosa, D. } \\
\text { caespitosa, Agrostis spp., } \\
\text { Holcus lanatus, bracken, } \\
\text { mosses }\end{array}$ & $\begin{array}{l}\text { Deschampsia flexuosa, Chamerion } \\
\text { angustifolium, Pteridium aquilinum, } \\
\text { Holcus mollis, Agrostis spp., Rubus } \\
\text { spp. }\end{array}$ & $\begin{array}{l}\text { Holcus lanatus, nettle, bramble, } \\
\text { bracken, Chamerion } \\
\text { angustifolium }\end{array}$ \\
\hline Provenances & 27 & 29 & 27 & 35 \\
\hline $\begin{array}{l}\text { Final } \\
\text { overstorey } \\
\text { removal }\end{array}$ & $\begin{array}{l}\text { Thinned and } \\
\text { high pruned; } \\
\text { never been } \\
\text { removed }\end{array}$ & $\begin{array}{l}\text { May } 1971 \text { and in Oct } 1973 \\
\text { windblow was cleared; } \\
\text { remainder removed Winter } \\
1977\end{array}$ & June 1979 & $\begin{array}{l}\text { In June } 1973, \text { SP affected by } \\
\text { Annosum root rot was removed; } \\
\text { Winter } 1986 \text { remainder } \\
\text { removed }\end{array}$ \\
\hline
\end{tabular}

More detailed information can be found in Tables S1 and S2 (Supplementary Material)

EL European larch (Larix europaea), SP Scots pine (Pinus sylvestris L.)

a Authorities follow Stace (1991)

(provenance 18, Table 3) at each experiment, except at Drummond Hill where side shade was provided by the unthinned overstorey surrounding the plot in each felled group.

All experiment sites were fenced against deer and were regularly weeded for the first 6 years after planting; hand weeding was the main method of controlling competing vegetation (Table $\mathrm{S} 1<$ supplementary material $>$ ). At the end of the first growing season, any dead trees were replaced at Benmore, Lael and Thetford, but this was not repeated in subsequent years. The overstories were thinned and/or removed in the 1970s or 1980s (records of this are not comprehensive, Table 2) during which the principle was to ensure the growth of the European silver fir understorey was not significantly compromised. No thinning has been carried out in any of the experimental plots, except at Thetford where access racks were cut in 1986. This involved removal of one row of trees from each plot to create two-row access racks that were two plots apart, reducing each plot from $6 \times 6$, to $6 \times 5$ trees. At Radnor, nine plots forming part of one block were lost due to windthrow after clearfelling of the adjacent stand sometime prior to the final assessment in winter 2011/12.

Survival and height of all plants at each site were recorded at regular intervals during the establishment period (Table 4). In winter 2011/12, all existing plots at Benmore, Radnor and Thetford were reassessed aged 46 years; unfortunately the plots at Drummond Hill could not be relocated and identified with sufficient confidence for reassessment. The number of trees per plot (survival), diameter at breast height (1.3 $\mathrm{m}$ above ground level) of all trees and height of the second largest diameter tree (as a conservative estimate of top height) were recorded in each plot. The form of each tree was also recorded using the following scoring system: 1 = single, straight clear stem and leader ('potentially excellent timber tree'); $2=$ single stem and leader but some kinks in main stem and/or heavy branching ('potential timber tree'); and $3=$ neither 1 nor 2 ('candidate to remove in early thinning'). All 2011/12 measurements were carried out by the same assessor to minimise measurement error.

An attempt was made to estimate volume using methods described by Matthews and Mackie (2006). However, the results were deemed to be inaccurate for a number of reasons, the most significant being the use of unplanted rows (i.e. linear gaps) in some experiments, which led to higher than expected basal areas. Instead, two approaches were used to give an indication of volume productivity. Firstly, a volume index (VI) was calculated by using the formula:

$\mathrm{VI}=D^{2} H$

where $D=$ quadratic mean diameter of the tree $(\mathrm{m})$; $H=$ height of second largest diameter tree (m).

Secondly, the general yield class $(\mathrm{GYC}$, the maximum mean annual increment in $\mathrm{m}^{3} \mathrm{ha}^{-1}$ year $^{-1}$ ) for each provenance at each site was estimated from top height-age relationships for noble fir in Edwards and Christie (1981). Calculations for the comparison plots of grand fir used relationships for grand fir, but for Caucasian fir, noble fir 
Table 3 Details of the provenances trialled at each of the sites

\begin{tabular}{|c|c|c|c|c|c|c|c|c|c|c|}
\hline $\begin{array}{l}\text { ID } \\
\text { code }\end{array}$ & $\begin{array}{l}\text { Provenance } \\
\text { ID No. }\end{array}$ & Region/forest ${ }^{\mathrm{a}}$ & Country & $\begin{array}{l}\text { Latitude } \\
\text { (all } \\
\text { North) }\end{array}$ & $\begin{array}{l}\text { Longitude } \\
\text { (all East } \\
\text { except } \\
35 \text { ) }\end{array}$ & $\begin{array}{l}\text { Altitude } \\
\text { (m) }\end{array}$ & Benmore & $\begin{array}{l}\text { Drummond } \\
\text { Hill }\end{array}$ & Radnor & Thetford \\
\hline 1 & $60(4361) 101$ & Hohe Wand & Austria & 47.5 & 16 & 800 & & & & $\mathrm{Y}$ \\
\hline 2 & 59 (4578) 100 & Calabria & Italy & 38.5 & 16.4 & 1,150 & $\mathrm{Y}$ & $\mathrm{Y}$ & $\mathrm{Y}$ & $\mathrm{Y}$ \\
\hline 3 & $60(4364) 100$ & Tyrol & Austria & 47.5 & 11.5 & 1,200 & $\mathrm{Y}$ & $\mathrm{Y}$ & & $\mathrm{Y}$ \\
\hline 4 & 59 (4578) 101 & Calabria & Italy & 38.5 & 16.5 & 1,300 & $\mathrm{Y}$ & $\mathrm{Y}$ & $\mathrm{Y}$ & $\mathrm{Y}$ \\
\hline 5 & $60(4578) 102$ & Calabria & Italy & 38.6 & 16.4 & 1,250 & & $\mathrm{Y}$ & $\mathrm{Y}$ & $\mathrm{Y}$ \\
\hline 6 & $60(4578) 103$ & Calabria & Italy & 38.6 & 16.4 & 1,250 & $\mathrm{Y}$ & $\mathrm{Y}$ & $\mathrm{Y}$ & $\mathrm{Y}$ \\
\hline 7 & 60 (437) 107 & Karlovice & Czech Republic & 50.2 & 17.3 & 850 & $\mathrm{Y}$ & $\mathrm{Y}$ & $\mathrm{Y}$ & $\mathrm{Y}$ \\
\hline 8 & $60(4943) 2$ & $\begin{array}{l}\text { Solothurn, Jura } \\
\text { Mountains }\end{array}$ & Switzerland & 47.2 & 7.5 & 740 & $\mathrm{Y}$ & $\mathrm{Y}$ & $\mathrm{Y}$ & $\mathrm{Y}$ \\
\hline 9 & 60 (4349) 100 & Ottenhöfen & Germany & 48.6 & 8.2 & 800 & $\mathrm{Y}$ & $\mathrm{Y}$ & $\mathrm{Y}$ & $\mathrm{Y}$ \\
\hline 10 & $60(4447)$ & $\begin{array}{r}\text { Lajoux, Jura } \\
\text { Mountains }\end{array}$ & France & 46.9 & 6 & 750 & $\mathrm{Y}$ & $\mathrm{Y}$ & $\mathrm{Y}$ & $\mathrm{Y}$ \\
\hline 11 & $60(4942) 4$ & Emmenthal & Switzerland & 47.1 & 7.8 & 1,060 & $\mathrm{Y}$ & $\mathrm{Y}$ & $\mathrm{Y}$ & $\mathrm{Y}$ \\
\hline 12 & $60(4383) 101$ & Southern Poland & Poland & 49.5 & 20.5 & 345 & $\mathrm{Y}$ & $\mathrm{Y}$ & $\mathrm{Y}$ & $\mathrm{Y}$ \\
\hline 13 & $60(455) 100$ & Tuscany & Italy & 43.75 & 11.6 & 1,010 & $\mathrm{Y}$ & $\mathrm{Y}$ & $\mathrm{Y}$ & $\mathrm{Y}$ \\
\hline 14 & $60(4439)$ & Vosges Mountains & France & 48.4 & 6.6 & 450 & $\mathrm{Y}$ & $\mathrm{Y}$ & $\mathrm{Y}$ & $\mathrm{Y}$ \\
\hline 15 & $60(4971) 102$ & Prusačka Rijeka & $\begin{array}{l}\text { Bosnia and } \\
\text { Herzegovina }\end{array}$ & 44.2 & 17.3 & 1,125 & $\mathrm{Y}$ & & & $\mathrm{Y}$ \\
\hline 16 & 60 (437) 104 & Červené Poříčí & Czech Republic & 49.5 & 13.5 & 450 & $\mathrm{Y}$ & $\mathrm{Y}$ & $\mathrm{Y}$ & $\mathrm{Y}$ \\
\hline 17 & $60(4942) 6$ & Graubünden & Switzerland & 46.75 & 9.5 & 1,220 & $\mathrm{Y}$ & $\mathrm{Y}$ & $\mathrm{Y}$ & $\mathrm{Y}$ \\
\hline 18 & $60(4459)$ & Puy de Dôme & France & 45.7 & 3.75 & 1,150 & $\mathrm{Y}$ & $\mathrm{Y}$ & $\mathrm{Y}$ & $\mathrm{Y}$ \\
\hline 19 & $60(4423)$ & St. Evroult & France & 48.75 & 0.5 & 300 & $\mathrm{Y}$ & $\mathrm{Y}$ & $\mathrm{Y}$ & $\mathrm{Y}$ \\
\hline 20 & 60 (4971) 101 & Sanski Most & $\begin{array}{l}\text { Bosnia and } \\
\text { Herzegovina }\end{array}$ & 44.8 & 16.7 & 760 & & & & $\mathrm{Y}$ \\
\hline 21 & 60 (437) 110 & Nízke Tatry & Slovakia & 48.8 & 19.7 & 700 & $\mathrm{Y}$ & $\mathrm{Y}$ & $\mathrm{Y}$ & $\mathrm{Y}$ \\
\hline 22 & 60 (437) 114 & Čierny Váh & Slovakia & 49 & 19.8 & 850 & & & $\mathrm{Y}$ & $\mathrm{Y}$ \\
\hline 23 & $58(4971)$ & $\begin{array}{l}\text { Pelister National } \\
\text { Park }\end{array}$ & Macedonia & 41.1 & 21.2 & 1,570 & & & & $\mathrm{Y}$ \\
\hline 24 & $60(4571) 100$ & Abruzzi & Italy & 41.6 & 14.7 & 1,200 & $\mathrm{Y}$ & $\mathrm{Y}$ & $\mathrm{Y}$ & $\mathrm{Y}$ \\
\hline 25 & 60 (437) 111 & Ľubochňa & Slovakia & 49 & 19.1 & 800 & $\mathrm{Y}$ & $\mathrm{Y}$ & $\mathrm{Y}$ & $\mathrm{Y}$ \\
\hline 26 & $60(4531) 100$ & Venetia & Italy & 46.6 & 12.2 & 1,450 & $\mathrm{Y}$ & $\mathrm{Y}$ & $\mathrm{Y}$ & $\mathrm{Y}$ \\
\hline 27 & $60(4365) 100$ & Klachau & Austria & 47.5 & 14 & 1,200 & & & & $\mathrm{Y}$ \\
\hline 28 & 59 (4972) 100 & Panitchishte & Bulgaria & 42.3 & 23.1 & 1,050 & $\mathrm{Y}$ & $\mathrm{Y}$ & $\mathrm{Y}$ & $\mathrm{Y}$ \\
\hline 29 & $60(4383) 100$ & Radom & Poland & 51 & 21 & - & $\mathrm{Y}$ & $\mathrm{Y}$ & $\mathrm{Y}$ & $\mathrm{Y}$ \\
\hline 30 & $60(4487)$ & La Betouze & France & 43 & 2.5 & 650 & $\mathrm{Y}$ & $\mathrm{Y}$ & $\mathrm{Y}$ & $\mathrm{Y}$ \\
\hline 31 & $60(4532) 100$ & Trento, Trentino & Italy & 45.9 & 11.2 & 1,225 & $\mathrm{Y}$ & $\mathrm{Y}$ & $\mathrm{Y}$ & $\mathrm{Y}$ \\
\hline 32 & $60(4971) 103$ & Zagreb mountains & Croatia & 45.9 & 16 & 900 & $\mathrm{Y}$ & $\mathrm{Y}$ & $\mathrm{Y}$ & $\mathrm{Y}$ \\
\hline 33 & $59(4482) 1$ & Ardèche & France & 45 & 4.5 & 1,100 & & $\mathrm{Y}$ & & $\mathrm{Y}$ \\
\hline \multicolumn{11}{|c|}{ Comparative species } \\
\hline 34 & $59(4792)$ & $\begin{array}{l}\text { Abies } \\
\quad \text { nordmanniana }\end{array}$ & Georgia & 43 & 44 & - & & $\mathrm{Y}$ & & $\mathrm{Y}$ \\
\hline 35 & $60(7975) 3$ & $\begin{array}{l}\text { Abies grandis from } \\
\text { Randle }\end{array}$ & Washington & 46.7 & 121.8 & 840 & $\mathrm{Y}$ & $\mathrm{Y}$ & $\mathrm{Y}$ & $\mathrm{Y}$ \\
\hline
\end{tabular}

\footnotetext{
${ }^{a}$ In some cases, there were slight changes to the area of seed collection within a provenance; more information is given in Table S7 $<$ Supplementary Material $>$

- Data not available
} 


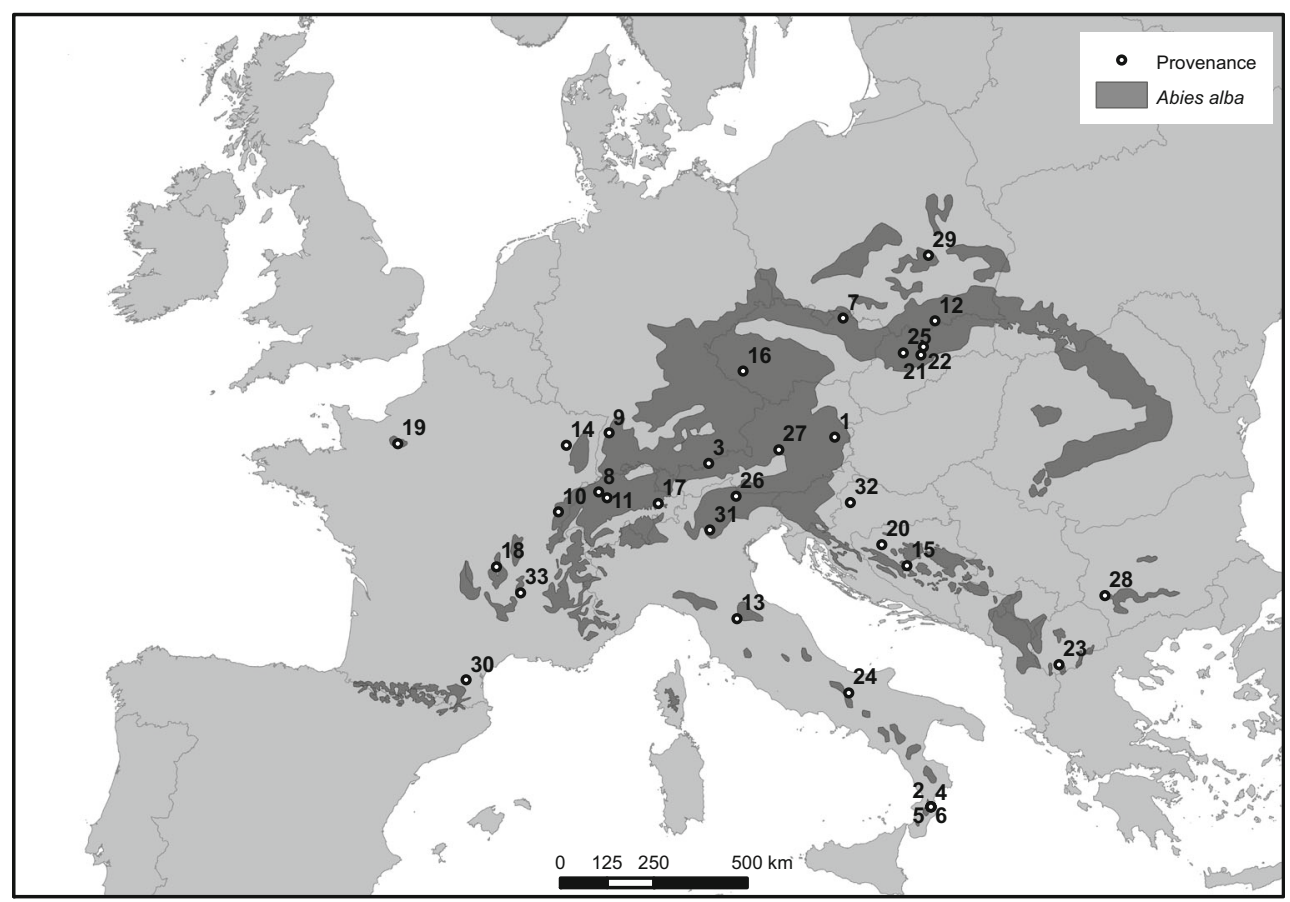

Fig. 2 Map of Europe showing location of provenances. Provenances are numbered to show the rank so the 'top 15' provenances are numbered $1-15$

was used. The guidance of Matthews and Mackie (2006) was followed to select appropriate alternative species to estimate GYC.

We attempted to explore potential relationships between provenance growth and climate at each test site, and the climate at provenance locations where seed was collected using temperature and precipitation climate variables taken from the Worldclim (www.worldclim.org) high-resolution dataset (Hijmans et al. 2005). However, correlations between growth parameters and climate variables were either non-significant, or correlated with the latitude of collection sites. Comparison between altitudes listed on file for the collection sites with those extracted for the grid referenced locations in Worldclim showed significant differences, suggesting that the coordinates reported for the collection sites are too imprecise to enable detailed analysis. The strongest relationship was between diameter growth and latitude of collection site, and this was explored further by fitting exponential models to the data from Benmore, Radnor and Thetford.

\section{Statistical analysis}

All analyses were to an extent compromised by the unbalanced distribution of provenances across sites, the unbalanced set of age assessment dates and the variable set of growth measurements recorded at each date. Consequently, it was only possible to compare subsets of provenances, ones where provenances had been planted at two or more sites and assessed for similar growth/survival statistics at similar ages. All statistical analyses were undertaken using Genstat 13 (Payne et al. 2009).

Height, diameter and form and survival of provenances were compared for the experiments at Benmore, Radnor and Thetford for the final assessment after 46 years. Generalised linear mixed models (GLMM) were used to identify significant effects of provenance, site and provenance/site interaction. Blocks within sites were fitted as random effects and any overdispersion accounted for by fitting an additional dispersion parameter. Similar GLMM models were fitted to 10-year-old height data assessed at Drummond Hill and Radnor and to age six heights and survival percentages assessed at Benmore, Radnor and Thetford. Finally, provenance differences were analysed at Benmore, Drummond Hill, Radnor and Thetford for survival and height growth at 3 years of age. In all cases, analyses were repeated excluding grand fir, to assess the sensitivity of the results to the inclusion of the species, which performed generally well on all sites.

Before fitting exponential models to the relationships between diameter and latitude, we checked to see whether survival and diameter were related at any of the sites by fitting linear regressions in which diameter was the dependent variable and provenance and survival were the explanatory variables. At Radnor $(p<0.001)$ and Thetford $(p<0.05)$, there were significant negative relationships, i.e. diameters increased with decreasing survival; however, 
Table 4 Assessments carried out at each experiment

\begin{tabular}{lllll}
\hline Year since & \multicolumn{2}{l}{ Trial site } & & \\
\cline { 2 - 5 } Planting & Benmore & Drummond Hill & Radnor & Thetford \\
\hline 0 & $\mathrm{~S}$ & $\mathrm{~S}$ & $\mathrm{~S}$ & $\mathrm{~S}$ \\
1 & $\mathrm{SH}$ & & $\mathrm{S}$ & \\
2 & & & $\mathrm{SH}$ & $\mathrm{H}$ \\
3 & $\mathrm{SH}$ & $\mathrm{SH}$ & $\mathrm{SH}$ & \\
6 & $\mathrm{SH}$ & $\mathrm{S}$ & $\mathrm{SH}$ & $\mathrm{H}$ \\
10 & & $\mathrm{SH}$ & $\mathrm{H}$ & \\
15 & & & & $\mathrm{SH}$ \\
46 & $\mathrm{SHDF}$ & & SHDF & SHDF \\
\hline
\end{tabular}

$S=$ survival assessment; $H=$ height assessment; $D=$ diameter assessment; $F=$ form assessment

it was clear from investigation of the plots that the survival of provenances from Calabria were close to the mean. Diameter was estimated for each provenance using the mean survival at each site (Benmore $28.3 \%$; Radnor $39.2 \%$, Thetford $23.4 \%$ ) after checking that the mean survival at each site was within the range of the majority of the provenances. Two sets of exponential models were then fitted to the data for latitude and (1) mean diameter for each provenance and (2) estimated mean diameter for each provenance.

Rank correlation analyses were used at Benmore, Radnor and Thetford to identify whether provenances showing improved growth and survival at early assessment ages (3, 6 and 10) maintained their advantage to the latest assessment at age 46. Least square means for height and survival data were used in these analyses to account for the frequent imbalance of provenances across experimental blocks within a site.

For presentation purposes, the 35 provenances represented in the experiments at Benmore, Radnor and Thetford were ranked according to the mean dominant height at age 46. The tallest provenance was given an identification code of ' 1 ' and the shortest provenance an identification code of '35' (Table 3). Figures 3, 4 and 5 are presented using a standard order of provenances from 1 (tallest, on the left) to 35 (shortest, on the right) to help clarify if and when the performance of provenances changes in the experiments. Each provenance code is followed by two letters to show its country of origin, e.g. Au is Austria and Fr is France.

\section{Results}

Establishment phase

Early survival in the experiments was good and to minimise the influence of replacing dead trees at the end of the first growing season, survival to the end of the sixth growing was examined. This ranged between $95.3 \%$ at Radnor, $89.3 \%$ at Benmore and $55.1 \%$ at Drummond Hill; survival at the end of the fifteenth growing season at Thetford was $69.2 \%$ (Fig. 3). The effects of provenance on survival were significant at $\operatorname{Radnor}(p=0.018)$ and Thetford $(p=0.039)$. The well known silvicultural characteristic of slow early growth of European silver fir was demonstrated at all sites, mean annual height increments (including the initial height of trees) ranged from $14.7 \mathrm{~cm} \mathrm{year}^{-1}$ at Thetford to $6.5 \mathrm{~cm}$ year $^{-1}$ at Radnor. The effects of provenance were significant for early height growth at all sites, and this result was not sensitive to the presence or absence of grand fir in the analysis (Fig. 4).

Final assessments at age 46

The effects of provenance on height were significant at Benmore, Radnor and Thetford (Fig. 5). At each site, the treatment with the tallest trees was the grand fir, but even if this was excluded from the analysis, there were still significant differences between the provenances (at Thetford provenance $1 \mathrm{Au}$ was the same height as the grand fir). Because final height was used to order the provenances for presentation, it can be seen that the better performing provenances are on the left hand side of Fig. 5 and it is noticeable that provenances from Calabria in Italy ( 2 It, 4 It, 5 It and 6 It) are consistently the tallest. The effect of provenance on mean diameter was also significant at all three sites, and there was a clear relationship with latitude (Fig. 6). Exponential models fitted to the mean observed diameter and to the estimated mean diameter (adjusted for survival) were similar, as the majority of provenance survival rates were close to the average for the site. It was clear from this relationship that the Calabrian provenances grew particularly well (Fig. 6). Although the superior growth of the Calabrian provenances is apparent in both the height and diameter data, it is particularly evident when the volume index is calculated (Fig. 7). In addition, results from the volume index show that 21 of the 29 other provenances have a volume index that is close (within $10 \%$ or above) to the mean. The median GYC of A. alba was 14 at Radnor (range 12-18), 16 at Thetford (range 10-20) and 18 at Benmore (range 14-22). The values for A. grandis were 14, 14, 22, respectively, at Radnor, Thetford, Benmore and 12 for A. nordmanniana at Thetford.

The effects of provenance on form score were only significant at Benmore $(p=0.031)$. However, in general, form scores were high and the means for each site were 1.96 for Benmore, 1.91 for Thetford and 2.25 for Radnor (Table 5); the lower figure at Radnor was probably caused by slow growth during establishment and bracken (Pteridium aquilinum (L.) Kuhn.) causing some trees to have 'sweep' in the lower $4 \mathrm{~m}$ of stem. 
Fig. 3 Mean percentage survival of provenances during early establishment at

a Benmore, b Drummond Hill, c Radnor and $\mathbf{d}$ Thetford. Data are for the end of the sixth growing season at Benmore, Drummond Hill and Radnor, and the end of the fifteenth growing season at Thetford (a) Benmore (GS6)

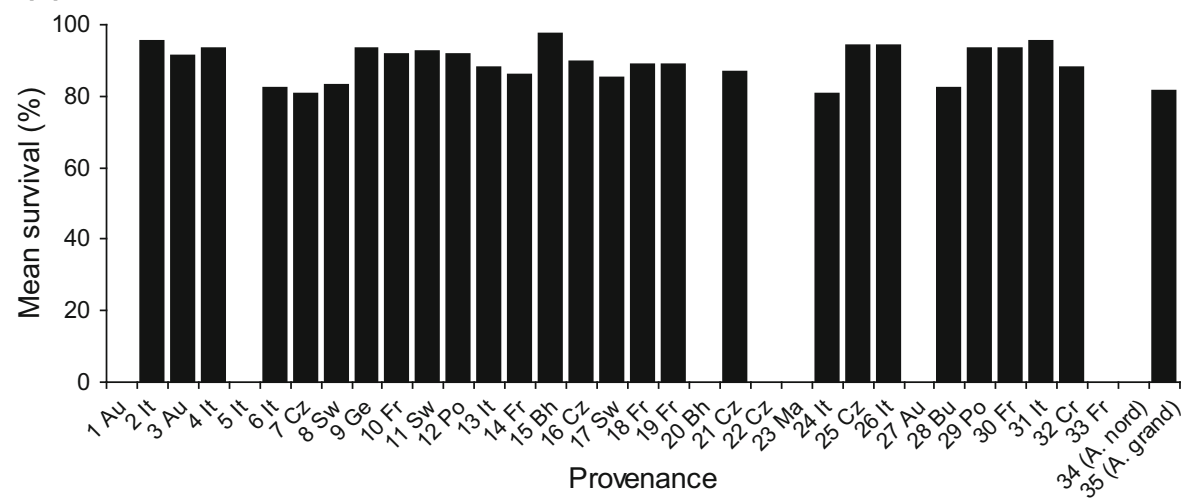

(b) Drummond Hill (GS6)

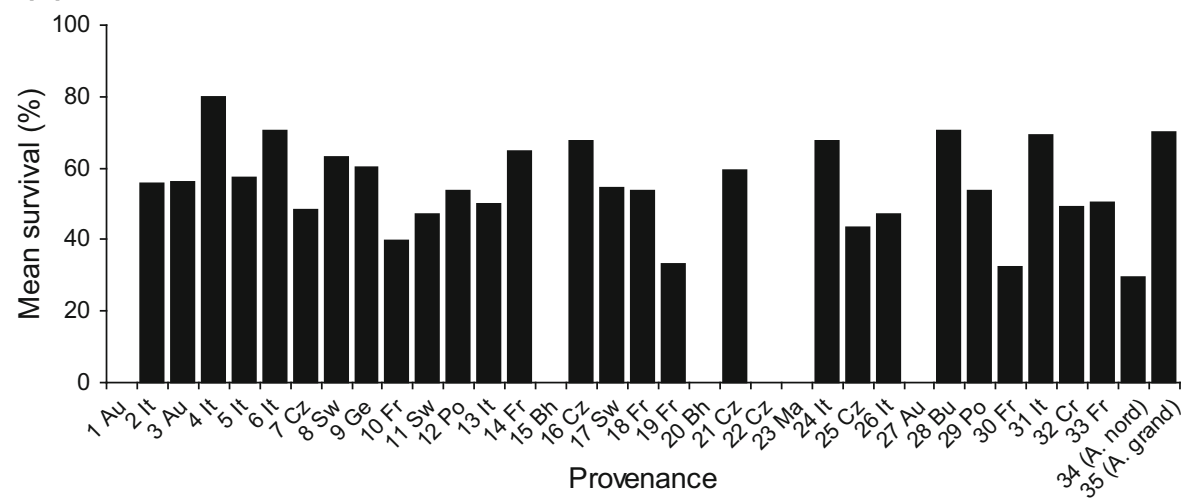

(c) Radnor (GS6)

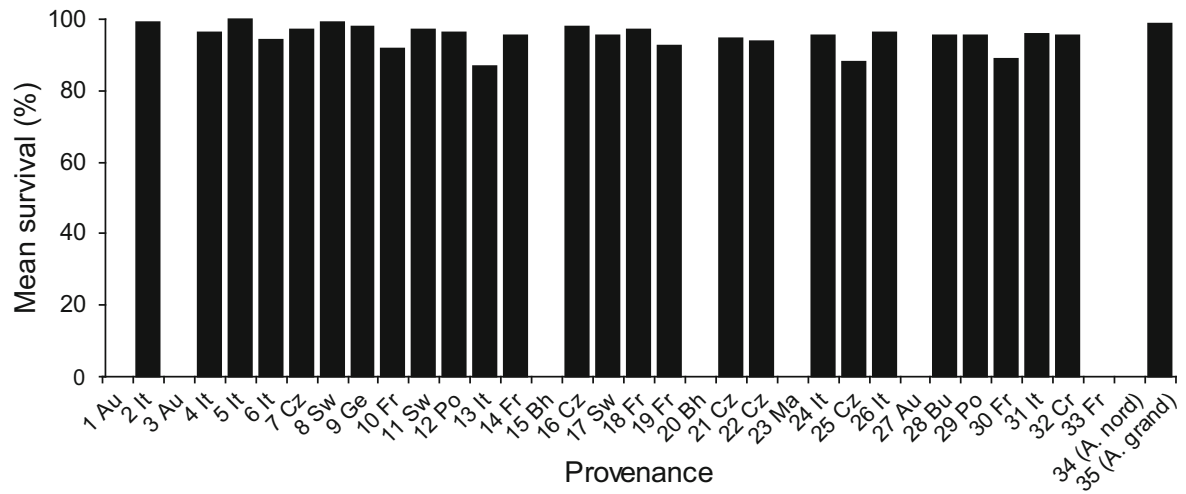

(d) Thetford (GS15)

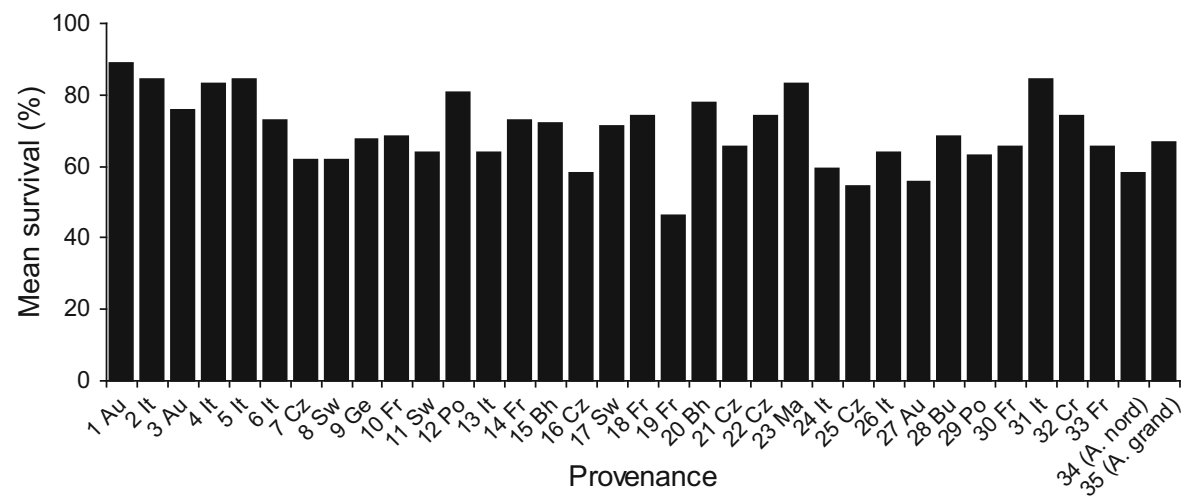


Fig. 4 Mean height (m) of provenances during early establishment at a Benmore, b Drummond Hill, c Radnor and d Thetford. Data are for the end of the sixth growing season at Benmore and Thetford, and the end of the tenth growing season at Drummond Hill and Radnor. Values are predicted means, and the bar shows the standard error of the difference (a) Benmore (GS6)

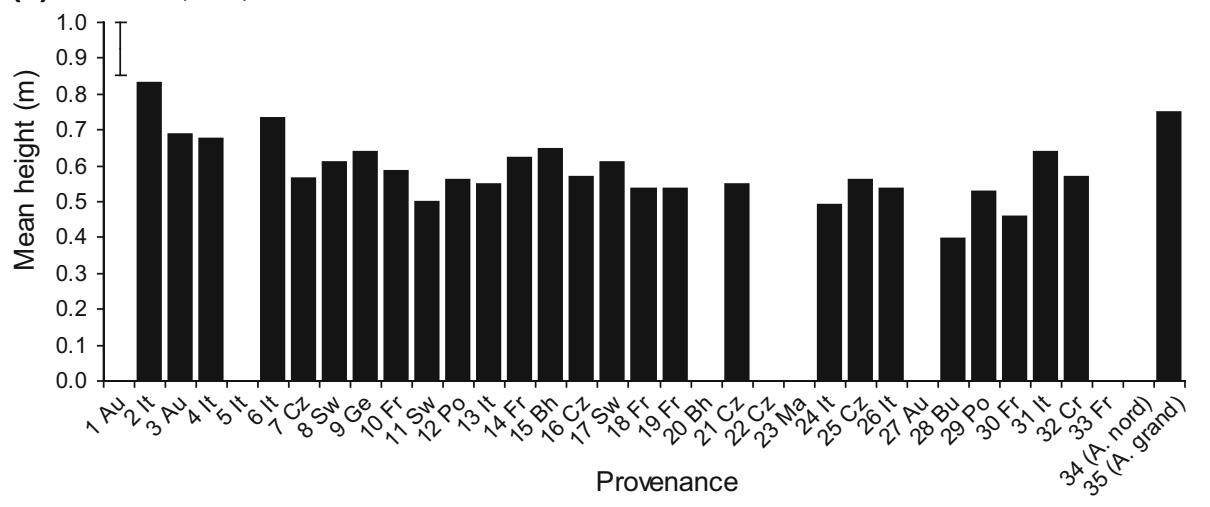

(b) Drummond Hill (GS10)

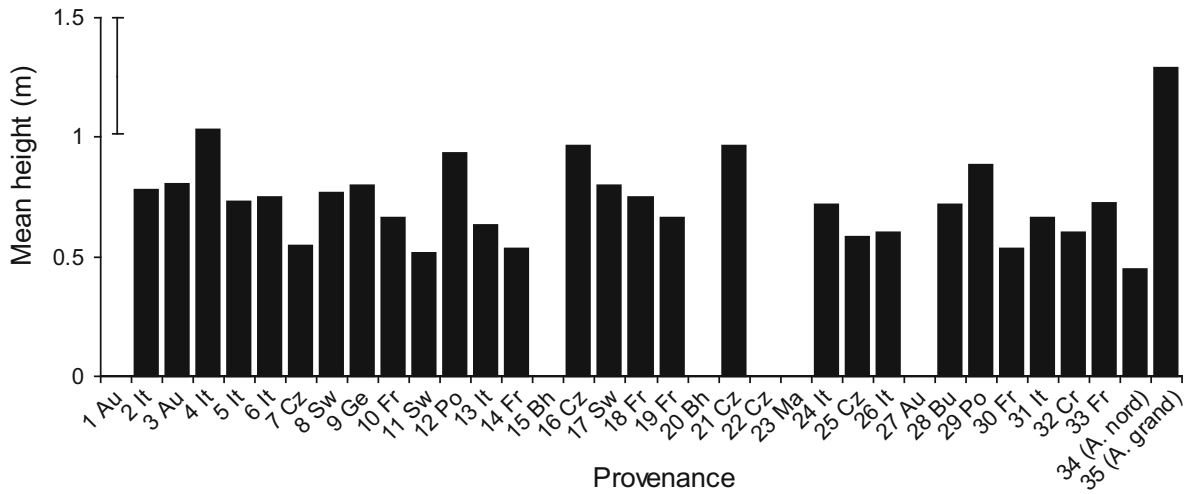

(c) Radnor (GS10)

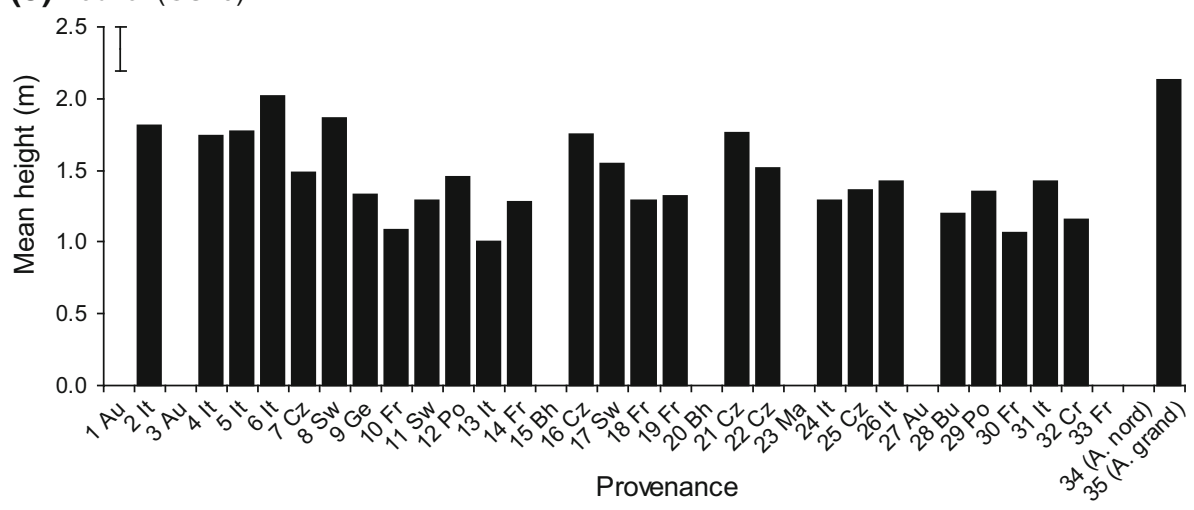

(d) Thetford (GS6)

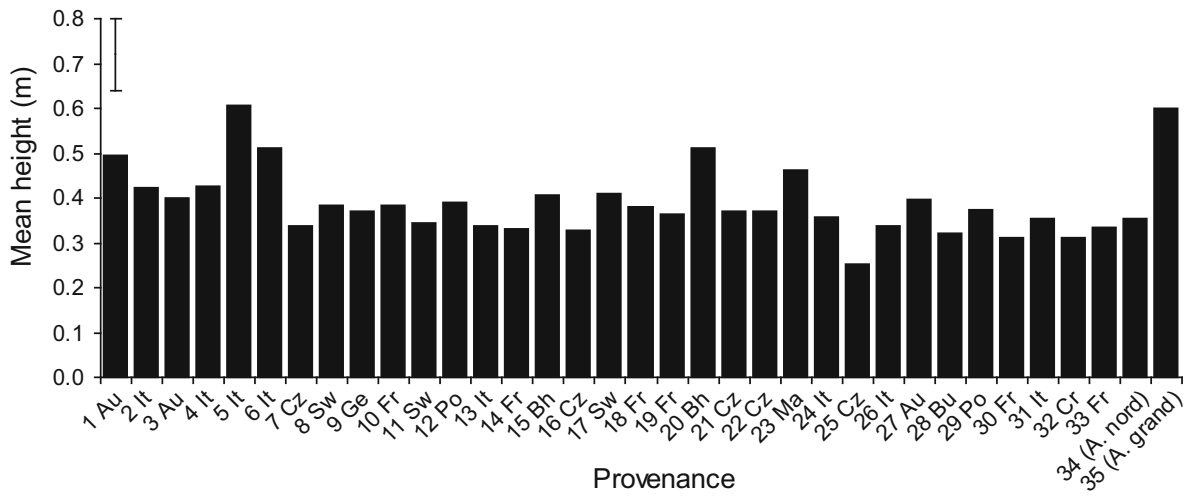


Fig. 5 Mean height (m) of provenances at the final assessment after 46 growing seasons at a Benmore, b Radnor and $\mathbf{c}$ Thetford. Values are predicted means, and the bar shows the standard error of the difference
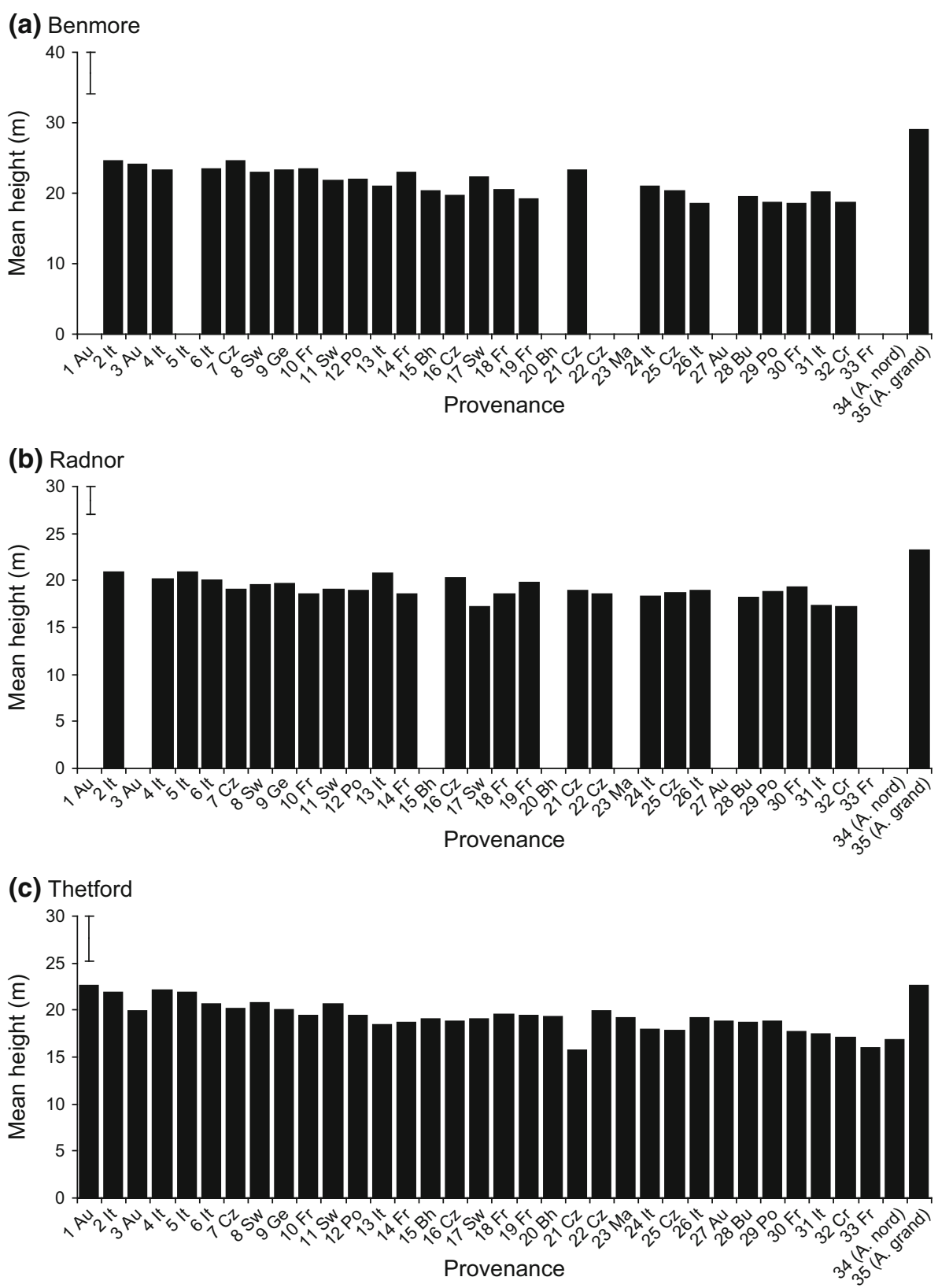

The age-age rank correlation analysis (Table 6) clearly shows that at all sites where there were three or more assessments there was no significant change of the ranking of provenances for both survival and height between the early assessments and the final assessment.

\section{Cross-site analysis}

The cross-site analysis at the end of the sixth growing season at Benmore, Radnor and Thetford showed that the height of 25 provenances was different between sites, i.e. the interaction between site and provenance was significant $(p<0.001)$ (Fig. 8a). However, when the final assessment data were analysed, this interaction was not present, i.e. the interaction between site and provenance was not significant (Fig. 8b). To illustrate this change, in the early data provenance 31 was ranked in the top third at Benmore, the middle third at Radnor and the bottom third at Thetford. However, in the final assessment, the performance of provenance 31 was more consistent and in the bottom third of rankings at Benmore, Radnor and Thetford. 
Fig. 6 Relationships between mean diameter after 46 growing seasons and latitude for the provenances and the fitted exponential relationship

\section{Discussion}

The three objectives of this paper are: (1) to examine the effect of provenance on the survival, growth and stem form of European silver fir in Britain; (2) to consider results in terms of important pests and pathogens of European silver fir in Britain; and (3) to review the role of European silver fir in the silviculture of forestry in Britain.

\section{Effects of provenance}

One of the main findings of the experiments reported here is that the difference in growth between the best and worst provenances was low. Across the three sites, the difference between the shortest and tallest provenance was $24 \%$ and variability in terms of volume index was also low. This result agrees with earlier work in Denmark examining 20 provenances at seven trial sites (Löfting 1954), which reported a difference of $20 \%$ between the worst and best provenances. Any discussion of the growth performance from these experiments must take account of the fact that generally the variation between provenances was generally low.

A question often asked of provenance experiments is: which one performed best and why? The answer to this question for European silver fir in Britain is Calabria (altitudes above $1,100 \mathrm{~m}$ ), and a possible explanation for this is that these areas of Italy were glacial refugia and have high levels of genetic diversity (Larsen and Mekic 1991). It should also be noted that the provenances from Calabria were the most southerly provenances tested and would have had a more oceanic climate than most other seed origins tested. The strong performance of the provenances from Calabria was also the conclusion reached by Lines (1987; p 7) based on an earlier examination of these trials and also compares well with Danish experiments (Hansen and Larsen 2004). Although it should be noted that 13 of the 17 provenances in the Danish study were from Calabria and four were from the altitudinal range $1,500-1,760 \mathrm{~m}$. However, the low variability between provenances found in the present studies suggests that other provenances will also survive and grow well in Britain.

Unfortunately, with the data available from this study it has not been possible to relate survival and growth closely to provenance locations to define other possible areas where seed may be collected. However, locations as close as possible and at a similar altitude and aspect to the 'top 15' sites
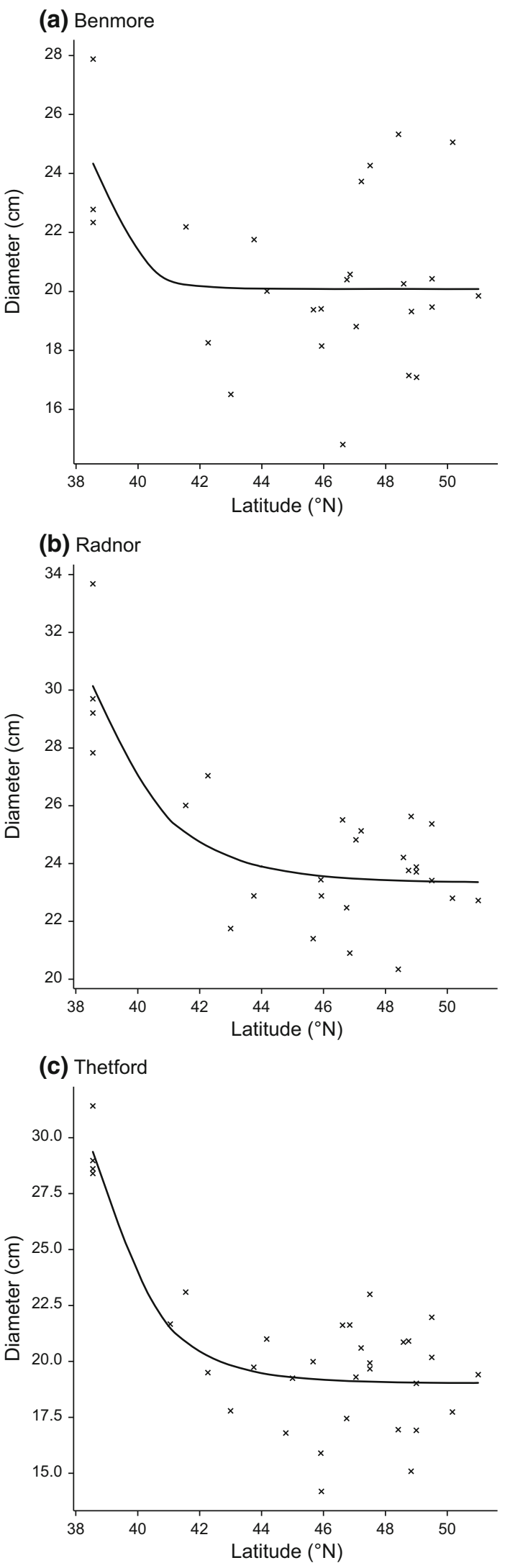


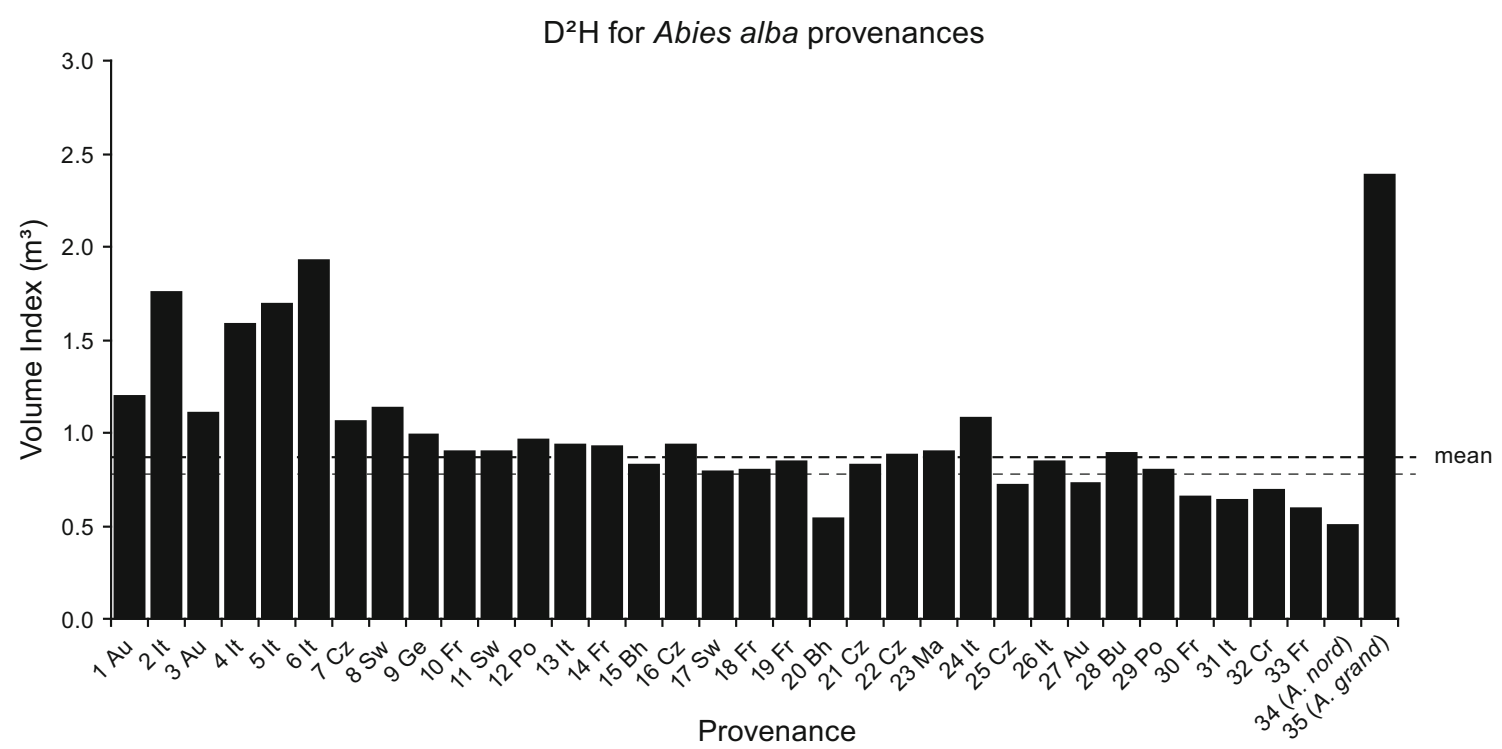

Fig. 7 Volume index for the 35 provenances calculated using a mean value for Benmore, Radnor and Thetford. Dotted lines show mean (top line) and $90 \%$ of mean (lower line)

Table 5 Summary of form scores at Benmore, Radnor and Thetford

\begin{tabular}{lllll}
\hline Site & $\begin{array}{l}\text { Mean form score (whole } \\
\text { site) }\end{array}$ & $\begin{array}{l}\text { Best scoring provenances (mean } \\
\text { score) }\end{array}$ & $\begin{array}{l}\text { Worst scoring provenance (mean } \\
\text { score) }\end{array}$ & $\begin{array}{l}p \text { value } \\
\text { (provenance) }\end{array}$ \\
\hline Benmore $^{\mathrm{a}}$ & 1.96 & $14 \mathrm{Fr}(1.87)$ & $19 \mathrm{Fr}(2.03)$ & 0.031 \\
Radnor $^{\mathrm{b}}$ & 2.25 & $17 \mathrm{Sw}(1.98)$ & $4 \mathrm{It}(2.53)$ & 0.140 \\
Thetford $^{\mathrm{c}}$ & 1.91 & $15 \mathrm{BH}(1.64)$ & $31 \mathrm{It}(2.13)$ & 0.133 \\
& & $26 \mathrm{It}(1.64)$ & & \\
\hline
\end{tabular}

${ }^{\mathrm{a}}$ A. grandis $=1.71$

${ }^{\mathrm{b}}$ A. grandis $=1.93$

${ }^{c}$ A. grandis $=1.71 ;$ A. nordmanniana $=2.00$

Table 6 Kendall's coefficient of concordance

${ }^{\text {a }}$ Not analysed-only 2 assessments available

\begin{tabular}{lllllc}
\hline Site & Assessment & No. of provenances & No. assessments & Chi squared & Probability \\
\hline \multirow{2}{*}{ Benmore } & Height & 26 & 3 & 55.9 & $<0.001$ \\
& Survival & 26 & 3 & 44.4 & 0.01 \\
\multirow{3}{*}{ Radnor } & Height & 26 & 4 & 67.1 & $<0.001$ \\
& Survival & 26 & 3 & 42.0 & 0.018 \\
\multirow{2}{*}{ Thetford } & Height $^{*}$ & 33 & 3 & 71.1 & $<0.001$ \\
& Survival $^{\text {a }}$ & & & & \\
\hline
\end{tabular}

shown in Fig. 2 would be likely to survive and grow well in Britain. Seed from other areas within the natural range of $A$. alba could also be considered if it has resulted from an improvement programme, i.e. is from a seed orchard.

One interesting result from the experiments concerns the changing nature over time of the interaction between site and provenance. Analysis of the early phase of growth indicated that the growth of provenances was strongly affected by site, which considering the differential impacts of soils, climate and silviculture is not surprising. However, for the final assessment many years later, the interaction between site and height was not significant. This is shown in Fig. 8 which shows that 'good' provenances of European silver fir generally adapt well to sites with very different 
Fig. 8 Heights at a age 6 and b age 46 for the 25 common provenances at Benmore, Radnor and Thetford (a) Heights of Abies alba provenances at age 6

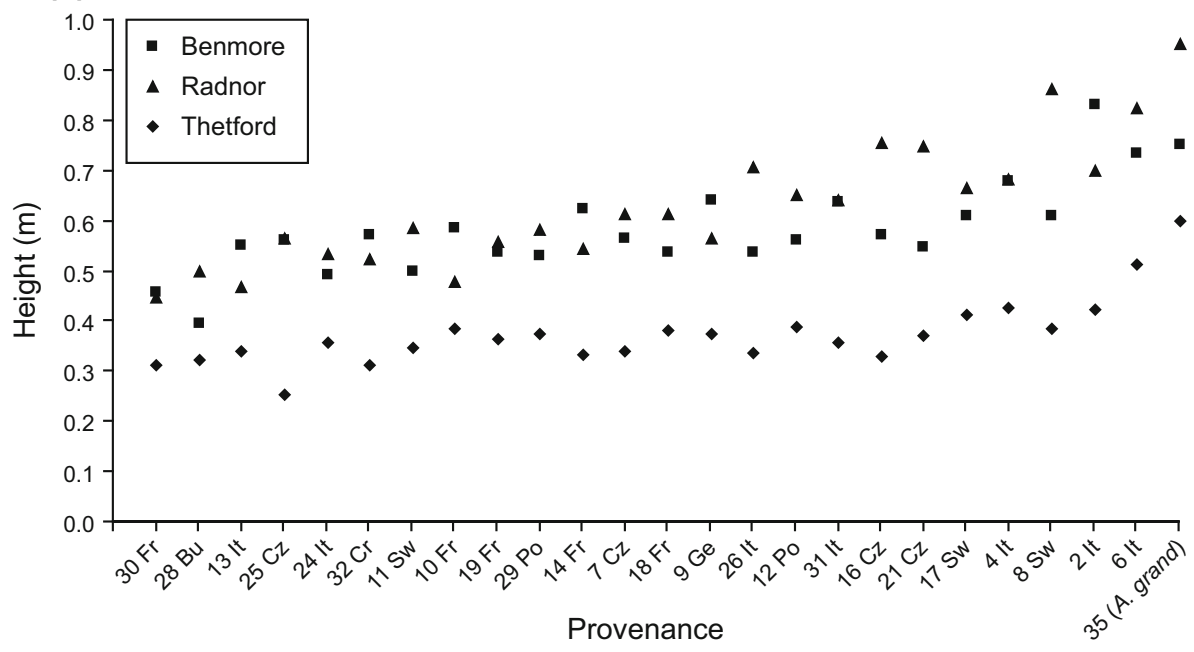

(b) Heights of Abies alba provenances at age 45

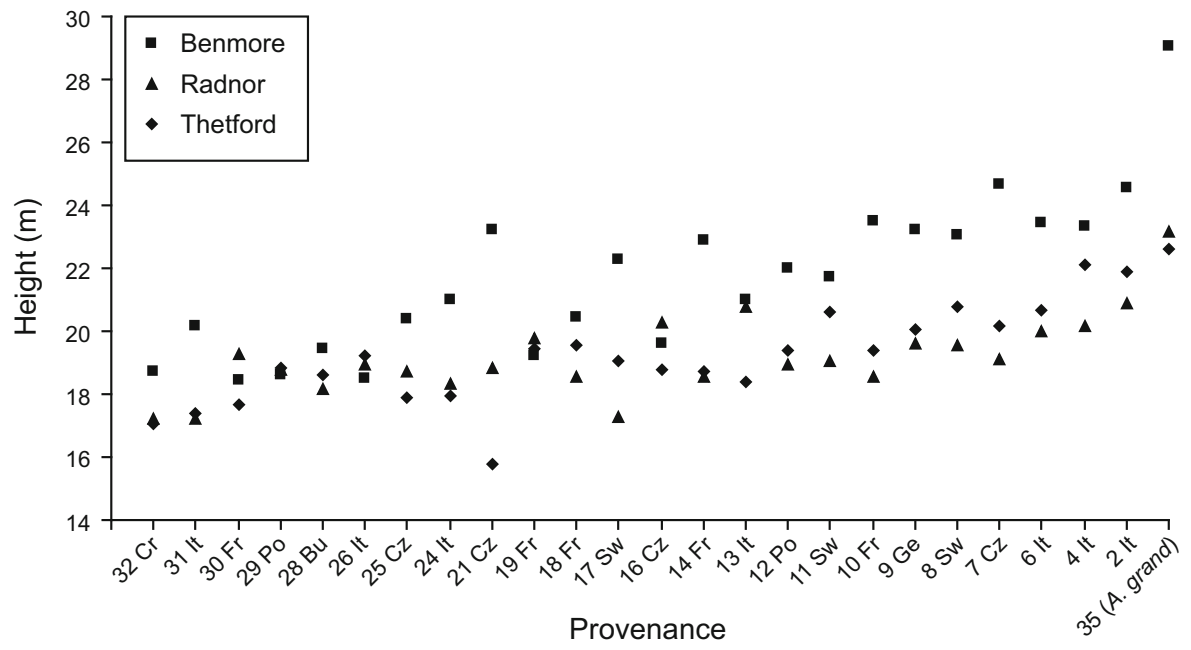

climate and edaphic characteristics. However, some caution is required here as in the early phase the heights of all trees were assessed, but in the final assessment, only one tree per plot was measured; it has also not been possible to take account of any overstorey effect. The practical interpretation of the lack of an interaction between site and provenance is that good provenances will grow well on suitable sites for the species throughout Britain.

The finding that there was a very strong correlation between the early and later results means that, in terms of the results for the different provenances, not much changed between 6 and 46 years. Hence, it is now possible to make the judgement that the main value of the experiments in their later life was to supply valuable information on silviculture, growth and the impacts of pests and pathogens. It is interesting to note the concern of Hansen and Larsen (2004) that after 15 years it is too early to make final conclusions concerning the Calabrian provenances compared with the ones from central Europe.

In general, the results from Lael and the three smaller trials described in $<$ Supplementary material $>$ support the results from the main experiments. The additional information from them is that the survival and growth of the Scottish provenance (Glendye Estate) and 14 Czech provenances was satisfactory.

Pests and pathogens

An objective of the experiments was to compare the effects of pests and pathogens between the provenances, 
particularly for Annosum root rot and the silver fir woolly aphid. Unfortunately, the planned assessments for this aspect of the study either did not take place or a copy of the data was not placed in the experiment file. Hence, the interpretation must therefore be based on recent observations of the experiments supplemented by notes and comments in the file. Three of the sites (Lael, Thetford and Drummond Hill) were selected to be established under overstories where there was known to be significant infection of Annosum root rot. Results from all sites suggest that survival was generally good, and there is no information to suggest that the young trees were affected by this pathogen. This seems to corroborate that the useful characteristic of being resistant to Annosum root rot in central Europe (Capretti et al. 1990) also applies when the species is planted in Britain.

The silver fir woolly aphid was noted at three of the sites; at Radnor, it was present at low levels between 1978 and 1984; at Benmore, it developed from being present in 1975 to being 'bad' in 1984 and then 'low' in 1986; there was also an infestation at Drumtochty in 1983 (Table S2 $<$ supplementary material>). Data from Hansen and Larsen (2004) support this level of presence; in their study at age 15 , the mean percentage of trees with an infestation was $3 \%$ (range $0-12 \%$ for the 17 provenances) and was unrelated to mortality $9 \%(0-24 \%)$ at the single site where it was assessed. This supports the claim of Kerr (1999) that the work of Varty (1956) was misinterpreted and the virtual suspension of planting reported by MacDonald et al. (1957) was an over-hasty response. Further evidence for this are the growth data produced by the experiments described above.

\section{Silviculture}

The main silvicultural characteristics of European silver fir are: slow early growth but capacity to produce high volumes of quality timber; windfirm and tolerant of exposure; shade tolerant; frost sensitive and high palatability to deer (MacDonald et al. 1957). These experiments have provided useful evidence that can be used to improve our understanding of the species and how it could be deployed in forests in Britain.

In terms of growth, the experiments have confirmed that the species does grow slowly in the first phase of its life, even with the good weed control for the first 6 years. The data of Hansen and Larsen (2004) also support this and show early growth of 9 and $13 \mathrm{~cm}^{-1}$ year ${ }^{-1}$ for two sites. However, the experiments also support the fact that following a slow phase of growth, which Lines (1960) considers to be up to 20 years, A. alba can produce high volumes of timber and results suggest that it should be possible to achieve GYC 12-18 with even higher values possible if provenances from Calabria are planted on sites where growth conditions are suitable. Grand fir was included in each of the four main experiments for comparison, and the results suggest that after 46 years the best provenances of A. alba are only slightly less productive. However, it should be noted that Lines (1979) considered that the provenance of grand fir included in the experiments was collected east of the Cascades and would be rather slow growing; however, the data do not support this concern. Although no information has been collected on timber properties, if the summaries of the two species in MacDonald et al. (1957) are correct, it is clear that A. alba has superior timber. The data on stem form showed that this was generally good except at Radnor where a bracken problem during establishment caused some stems to disfigure.

In terms of the other silvicultural characteristics of the species being windfirm, tolerant of exposure, shade tolerant, sensitive to frost and highly palatable to deer, the results from the experiments cannot contribute much objective information. However, it should be noted that browsing damage was one of the main factors for the loss of the Lael site and also caused significant damage at Drummond Hill. One anecdote worthy of note was the capercaillie (Tetrao urogallus) regarded A. alba as a 'special delicacy' (according to Lines 1979) and it suffered damage at Drummond Hill.

Results from the experiments have demonstrated that $A$. alba can be grown successfully as a plantation species in Britain. However, some care is required interpreting this as the largest of the experiments occupied an area of approximately two hectares, and all plots were surrounded by species of different genera. If the species was planted on a very large scale, there remains a risk that populations of the woolly aphid could build up to significant levels and cause severe damage. However, is this the best way of deploying this valuable tree species in the forests of Britain? Kerr (1999) advocated its use as a component of mixed species, uneven-aged woodlands; initially, this would involve underplanting for which it is well suited because of its shade tolerance. This would seem to be the best way to deploy the species in view of its silvicultural characteristics and the policy need to diversify forests to increase resilience to climate change and pests and diseases. However, the problem of being highly palatable to deer browsing and slow early growth remain, and are likely to be the main factors influencing its use in Britain, whereas previously it was concerns about the woolly aphid.

\section{Conclusions}

1. European silver fir is a productive species that could be used more widely to diversify forests to increase resilience to climate change and pests and diseases. 
2. On three contrasting sites in England, Scotland and Wales, the yield of the provenances planted varied between GYC 12-22 at age 46.

3. Based on the results of this study, the best provenances for use in Britain are (in priority order): (1) from Calabria (the 'toe' of Italy) at $1,100 \mathrm{~m}$ or more above sea level; (2) from areas near to the 'top 15' sites from this study (see Fig. 2) and at a similar altitude; (3) from areas within the natural range of $A$. alba in Europe where improved seed is available from seed orchards.

4. Good provenances tend to grow well on sites suitable for European silver fir throughout Britain; there is no evidence from the experiments described to select different provenances to suit climate and edaphic conditions.

5. The results of the study corroborate the fact that the species is resistant to Annosum root rot and that the previous advice not to plant the species because of the risks of damage caused by the woolly aphid may have been overstated.

Acknowledgments Experiments were designed by Roger Lines of Forest Research and preserved over the years by many others. We would like to thank many Forest Research Technical Services staff for establishing and maintaining the experiments, and in particular Lee Cooper for carrying out the 2011/12 assessments. Steve Lee, Helen McKay and two anonymous reviewers offered comments that helped to greatly improve the paper. Bill Rayner helped to clarify the soil descriptions at each site from the written records. We are also grateful to EUFORGEN (http://www.euforgen.org/) for permission to publish their map of the native range of A. alba used in Fig. 2.

Open Access This article is distributed under the terms of the Creative Commons Attribution License which permits any use, distribution, and reproduction in any medium, provided the original author(s) and the source are credited.

\section{References}

Capretti P, Korhonen K, Mugnai L, Romagnoli C (1990) An intersterility group of Heterobasidion annosum specialized to Abies alba. Eur J For Pathol 20:231-240

Edwards PN, Christie JM, (1981) Yield models for forest management. Forestry Commission Booklet 48. HMSO, London

Forestry Commission (2011) National Forest Inventory Woodland Area Statistics for Great Britain. http://www.forestry.gov.uk/pdf/ NFI_GB_woodland_area_stats_2010_FINAL.pdf/\$FILE/NFI_GB_ woodland_area_stats_2010_FINAL.pdf. Accessed 17 Nov 2014

Hansen JK, Larsen JB (2004) European silver fir (Abies alba Mill.) provenances from Calabria, southern Italy: 15-year results from Danish provenance field trials. Eur J For Res 123:127-138

Hijmans RJ, Cameron SE, Parra JL, Jones PG, Jarvis A (2005) Very high resolution interpolated climate surfaces for global land areas. Int J Climatol 25:1965-1978
Jahn E (1976) The influence of some site factors on Dreyfusia (Adelges) nusslini. Anzeiger fur Schadlingskunde Pflanzenschutz Umweltschutz 49(7):97-99

Kennedy F (2002) The identification of soils for forest management: a field guide. Forestry Commission, Edinburgh

Kerr G (1999) European silver fir (Abies alba) in Britain: time for a reassessment. Q J For 93:294-298

Kohnle U, Kändler G (2007) Is Silver fir (Abies alba) less vulnerable to extraction damage than Norway spruce (Picea abies)? Eur $\mathbf{J}$ For Res 126:121-129

Larsen JB, Mekic F (1991) The geographic variation in European silver-fir (Abies alba Mill.). Silvae Genet 40:188-198

Lines R (1960) Common silver fir in Britain. Scott For 14(1):20-30

Lines R (1979) Natural variation within and between silver firs. Scott For 33:89-101

Lines R (1987) Choice of seed origins for the main forest species in Britain. Forestry Commission Bulletin 66. HMSO, London

Lofting ECL (1954) Danmarks aedelgranproblem. Forstl Forsogsv Danm. 21:337-381

MacDonald J, Wood RF, Edwards MV, Alhous JR (1957) Exotic forest trees in Great Britain. Forestry Commission Bulletin 30. HMSO, London

Mason WL (2013) The role of true fir species in the silviculture of British forests: past, present, and future. Kastamonu Univ J For Fac 12(3):15-26 Special Issue 2012

Matthews R, Mackie E (2006) Forest mensuration: a handbook for practitioners. Forestry Commission, Edinburgh

Maw PT (1912) Complete yield tables for British woodland and the finance of British forestry. Crosby Lockwood and Son, London

Metzler B, Hecht U, Nill M, Brüchert F, Fink S, Kohnle U (2012) Comparing Norway spruce and silver fir regarding impact of bark wounds. For Ecol Manag 274:99-107

Paterson DB (1990) The potential to apply different silvicultural systems to upland British forests, predominantly of Sitka spruce. In: Silvicultural Systems (Ed. Gordon, P.). Proceedings of on Institute of Chartered Foresters Discussion Meeting, University of York, 6-8 April 1990. Institute of Chartered Foresters, Edinburgh

Pavari A (1951) Esperienze e indagini su le provenienze e razze dell Abete bianco (Abies alba Mill.). Nuovi Annali della Sperimentazione Agraria. Serie No. 8

Payne RW, Murray DA, Harding SA, Baird DB, Soutar DM (2009) GenStat for windows (13th Edition) introduction. VSN International, Hemel Hempstead

Pringle D (1994) The first 75 years: a brief account of the history of the Forestry Commission, 1919-1994. Forestry Commission, Edinburgh $103 \mathrm{pp}$

Puettmann K, D'Amato AW, Kohnle U, Bauhus J (2009) Individual tree growth dynamics of mature Abies alba during repeated irregular group shelterwood (Femelschlag) cuttings. Can J For Res 39:2437-2449

Pyatt G, Ray D, Fletcher J (2001) An ecological site classification for forestry in Great Britain. Forestry Commission Bulletin 124. Forestry Commission, Edinburgh

Ray D (2000) Ecological site classification decision support system (May 2000). Forest Research, Northern Research Station, Edinburgh. http://www.eforestry.gov.uk/forestdss/

Stace CA (1991) New flora of the British Isles. Cambridge University Press, Cambridge

Varty IW (1956) Adelges Insects of Silver Firs. Forestry Commission Bulletin 26. HMSO, London 